\author{
IНТЕГРОВАНЕ НАВЧАННЯ ПРЕДМЕТА \\ Й IHОЗЕМНОÏ МОВИ У ВИЩІЙ ШКОЛІ \\ INTEGRATED LEARNING OF SUBJECT \\ AND FOREIGN LANGUAGE AT HIGH SCHOOL
}

УДК 378.091.313: 811.111

DOI https://doi.org/10.32843/2663-60852019-13-2-11

\section{Александров В.М.,}

канд. пед. наук, доцент кафедри

викладання другої іноземної мови

Запорізького національного

університету

Александрова О.Ф.,

канд. пед. наук,

доцент кафредри іноземних мов

просресійного спрямування

Запорізького національного

університету

\begin{abstract}
Стаття присвячена одній із актуальних проблем підготовки майбутніх учителів у вищій школі - інтегрованому навчанню предмета й мови. Зокрема, розкривається сутність таких понять, як міжпредметна інтеграція, інтегроване навчання, іншомовне навчальне середовище. Основну увагу зосереджено на теоретико-методичних засадах профессійної підготовки майбутніх учителів іноземної мови для багатомовної школи. Висвітлюються цілі, принципи, структурні компоненти методики CLIL та особливості її впровадження у вищій школі. У найбільш спрощеному вигляді розглядаються можливості створення загальної мовної підтримки для одночасного засвоєння спеціальних предметів та оволодіння іноземною мовою, що стає надійною основою іншомовної профресійної компетенції. Розроблення й координація навчальних і предметних програм, узгодження їх змісту різними кафредрами, наступна корекція всього процесу інтегрованого навчання з урахуванням результатів педагогічної практики студентів можуть суттєво підвищити ефективність професійної підготовки майбутніх фрахівців у вищій школі. На основі аналізу психологопедагогічної літератури обгрунтовуються можливості застосування цієї методики для навчання різних спеціальностей у вищій школі. Зазначається також, що концепція дослідження забезпечується єдністю методологічного, теоретичного та методичного аспектів. Розвиток системного процесу інтегрованого навчання предмета й мови також має враховувати загальні особливості психіки тих, хто навчається. Існує нагальна потреба подальшого вивчення психологічних особливостей навчання студентів різних спеціальностей, тому що психологічні умови навчання іноземних мов різних категорій майбутніх фрахівців $є$ до останнього часу однією з найменш досліджених проблем. Таке ускладнене завдання передбачає інтегровану співпрацю викладачів кафредри психології й кафредри іноземних мов, а під час педагогічної практики майбутніх учителів іноземних мов необхідною стає допомога психолога школи. Ключові слова: міжпредметна інтеграція, інтегроване навчання предмета й мови, психологія процесу інтегрованого навчання, іншомовне навчальне середовище.
\end{abstract}

The article is devoted to one of the urgent problems of preparing future teachers of a foreign language in high school by means of Content and Language Integrated Learning method. In particular, the essence of such concepts as integration, integrated learning, foreign language learning environment, teacher's value orientations are revealed. The main focus is on the theoretical and methodological principles of training future teachers of a foreign language in a multilingual school. The aims, principles, structural components of the CLIL methodology and the peculiarities of its implementation in high school are highlighted. In the most simplified way we research the opportunities for creating general linguistic support to master special subjects simultaneously with a foreign language, which would become a reliable basis for foreign language professional competence. The development and coordination of educational and subject programs, harmonization of their content by different departments, the subsequent correction of the whole integrated learning process, taking into account the results of students' pedagogical practice, can significantly improve the efficiency of professional training of future specialists in high school. On the basis of the analysis of psychological and pedagogical literature the possibilities of introduction of this method for teaching different specialties in high school are grounded. It is also noted that the concept of research is ensured by the unity of methodological, theoretical and methodological aspects. The development of integrated learning subject and language system process should also take into account the psychics peculiarities of those who study. There is an urgent need for further studies of the psychological characteristics in teaching various specialties. The psychological conditions of teaching foreign languages in different specialties remain today still an unstudied problems. Such a complicated task involves the close cooperation of teachers belonging to different Departments: i.e. Psychology and Foreign Languages. And it also makes acute the assistance of school psychologist during the pedagogical practice.

Key words: interdisciplinary integration, content and language integrated learning, psychology of the educational process, foreign language teaching environment.
Постановка проблеми в загальному вигляді. На етапах великих перетворень, коли суспільство переживає економічну, політичну, соціальну та культурну кризу, проблеми профресійної підготовки майбутніх фрахівців у вищій школі набувають особливого значення. Сучасна вища школа має не лише навчати майбутніх учителів просресійно-орієнтованої іноземної мови, а й інтегровано фрормувати систему їхніх ціннісних орієнтацій засобами педагогіки, методики, фрілософії, релігієзнавства, шедеврами світової літератури тощо. У Європі методику інтегрованого навчання пред- 
мета й мови, або CLIL (анг. Content and Language Integrated Learning), запроваджено в 1984 році. Згідно з фрілософрією інтегрованого навчання предмета й мови, вивчення іноземної мови не $є$ самоціллю. Оволодіння іноземною мовою відбувається за допомогою тематики предметів, що є професійно необхідними та цікавими для студентів. Сутність професії, яка системно представлена через іноземну мову, спонукає до дій і стає головним орієнтиром у виборі мети навчальної діяльності. Така інтегрована діяльність залежить від того, наскільки успішною буде співпраця викладача іноземної мови й викладача-предметника для створення іншомовного навчального середовища для використання його властивостей у процесі навчання студентів предметів професії та іноземної мови. На нашу думку, навчання майбутніх фрахівців засобами CLIL стає значущим і має відбуватися саме в такому контексті в сучасній вищій школі.

Усе вищезгадане зумовлює актуальність дослідження сучасних фрорм інтегрованого навчання майбутніх учителів іноземних мов, які можуть бути впроваджені в вищій школі та підвищити ефективність вищої педагогічної освіти загалом.

Аналіз останніх досліджень і публікацій. Проблеми інтегрованого навчання у вищій школі, які сьогодні вивчаються низкою вчених, охоплюють фрундаментальні положення педагогічної, психологічної та методичної наук, а саме: перспективи розвитку професійної освіти й підготовки педагогів нової генерації (І.А. Зязюн, Н.Г. Ничкало, O.І. Щербак); принципи організації профресійноорієнтованого навчання іноземної мови у вищій школі (О.Б Тарнопольський, Л.М Черноватий); інтегрований підхід до викладання іноземної мови (Н.О. Морська); концептуальні засади індивідуалізації іншомовного навчання (С.Ю. Ніколаєва); концепція моделі інтегрованого навчання й технологія її впровадження в навчальний процес вищої школи (М.О. Сова). Теоретичні положення методики інтегрованого навчання предмета й мови у вищій школі досліджували відомі зарубіжні вчені: Д. Марш, Ф. Худ, Д. Койл, І. Маккензі, М. Раннут, К. Райк.

Виділення не вирішених раніше частин загальної проблеми. Досягнення профресійної досконалості робить очевидною необхідність застосування інтегрованого навчання майбутніх учителів і координації між заняттями з дисциплін спеціалізації та практичними заняттями з методики навчання іноземної мови, де набуті педагогічні й спеціальні знання повинні адаптуватися в заданих межах конкретної іншомовної комунікативної компетенції. Сьогодні в багатьох випадках навчальний процес вищої школи відповідає принципу: зараз вивчай, потім будеш користуватися. Як правило, планування предметів спеціальності й занять 3 іноземної мови відбувається на різних кафедрах та узгоджується викладачами досить фрормально. У більшості кафредр вищої школи не існує жодних загальних вимог чи рекомендацій щодо організації інтегрованого навчання предмета й іноземної мови для своїх студентів. Деякі немовні кафедри надають право викладати предмет іноземною мовою своїм викладачам-предметникам, які володіють професійно-орієнтованою іноземною мовою, але не володіють теорією та методикою навчання іноземних мов як наукою.

Іншою проблемою $є$ те, що викладачі спеціальних предметів не завжди активно співпрацюють із викладачами іноземної мови й досить рідко підкріплюють зміст своїх занять із предмета іншомовним матеріалом у вигляді реклами, інструкцій, таблиць, графіків тощо. Це означає, що студенти немовних спеціальностей мають обмежені можливості для використання набутих іншомовних навичок і вмінь на заняттях зі спеціальності. Саме тому викладачі спеціальних предметів повинні розширювати іншомовний зміст своїх занять, так само як викладачі іноземної мови в процесі навчання мови мають використовувати знання інших предметів (наук) [1, с. 111].

Безперечно, перспективним для методичного контексту проблеми інтегрованого навчання майбутніх учителів має стати врахування принципу визначення змісту навчання на основі першочергового вивчення характеру майбутньої діяльності (content-based approach), що передбачає пріоритет предметного складника над мовним. Дотримання цього принципу в навчанні іноземних мов сприяє ефективному відбору лексичного і граматичного іншомовного мінімуму, який може бути достатнім для комунікації у відповідних ситуаціях спілкування, створюючи сприятливі можливості для досягнення практичної мети за відносно стислий термін. На заняттях 3 іноземної мови викладач має використовувати мову в цільовому контексті (спеціальну термінологію, тексти), допомогти студентам оволодіти знаннями конкретної спеціальності засобами іноземної мови. Маючи низку переваг, інтегроване навчання мови дає змогу поєднувати тематичний і нетематичний (не об'єднаний однією тематикою) алгоритм проведення занять. Обрана тема має бути профресійно спрямованою, інфрормативною, цікавою для студентів, а також давати велику кількість спеціальної лексики та мовних форм. Інтегрований підхід, який природно передбачає й гуманістичний підхід до навчання, дає можливість створити позитивну емоційну атмоссреру. Таку сприятливу атмоссреру утворює об'єднаний соціокультурною інсрормацією стимулювальний характер заняття, який відповідає темі, що вивчається. Інтегрований підхід розглядають як такий, що дає змогу застосовувати на заняттях різні види роботи, спрямовані на розвиток і вдосконалення іншомовних навичок і мов- 
леннєвих умінь в аудіюванні, говорінні, читанні та письмі. Така фрорма інтегрованого навчання іноземної мови передбачає здійснення поступового переходу від мовленнєвої розминки до наступного виконання вправ і завдань, організації групової дискусії [2, с. 19].

Доцільно також зауважити, що на старших курсах зростає кількість спеціальних предметів, які викладають іноземною мовою, де саме й відбувається інтеграція спеціальних знань із предметів і цільового використання мовних навичок і мовленнєвих вмінь. Тільки за цієї умови реалізують основний принцип інтегрованого навчання: вивчай і використовуй водночас. Важливим фрактором $€$ також наявність відповідного аутентичного навчального матеріалу, а тексти й завдання мають бути пов'язані з конкретними професійними цілями та реальними комунікативними ситуаціями [6, с. 14].

Метою статті $€$ висвітлення структурних компонентів педагогічного, психологічного й методичного характеру, необхідних для вдосконалення процесу інтегрованого навчання предмета й мови у вищій школі.

Виклад основного матеріалу. Ідея інтегрованого навчання предмета й мови може трактуватися як відбір та об'єднання навчального матеріалу різних предметів з метою цілісного, системного, різнобічного вивчення спеціальності; як створення такого інтегрованого змісту професійного навчання, що об'єднує знання різних предметів у єдиний цілісний багатосторонній фрокус. Стаття розглядає в найбільш спрощеному вигляді можливості створення загальної мовної підтримки для одночасного засвоєння спеціальних предметів та оволодіння іноземною мовою, що стає надійною основою іншомовної профресійної компетенції.

У сучасній вищій школі вдосконалення навчального процесу на якісно новому рівні може відбутися за умови розвитку міжпредметних зв'язків до рівня міжпредметної інтеграції. Серед основних принципів такого інтегрованого навчання можна виділити такі: цілісності, системності, структурності, багаторівневості, відповідності дидактичної системи соціальним і культурним сферам суспільного життя. Реалізація зазначених принципів дає можливість оптимізувати навчальний процес, а фрункціонування інтегрованої дидактичної системи може проходити на рівні навчальної теми; на рівні навчального модуля; на рівні навчального предмета; на рівні системної цілісності навчальних циклів [4, с. 11].

Кожна навчальна програма складається 3 модулів, що, у свою чергу, включають навчальні предмети. Різні університети встановлюють свої форми навчальних і предметних програм. Сьогодні як ніколи необхідна спільна робота викладачів різних предметів (укладачів навчальних програм) для узгодження тематики навчального матеріалу з метою створення багатобічного фрокусу спеціальності. Такий багатобічний фрокус включає тематичний зміст різних предметів конкретної спеціальності, обговорений та узгоджений усіма викладачами в найбільш логічній тематичній послідовності, яка буде враховувати зміст предметів та аспекти мови в найбільш логічному вигляді. Розвиток навчальних програм вимагає постійної співпраці й поточного моніторингу ефективності результатів навчання (learning outcomes) протягом усього навчального курсу до проведення державних іспитів, коли стає зрозумілим те, що майбутні вчителі іноземних мов знають і вміють. Після цього має відбуватися нова корекція процесу інтегрованого навчання, узгодження змісту навчальних і предметних програм. У європейських закладах вищої освіти створюють спеціальні ради з навчальних програм, які відповідає за їі аналіз і розвиток. До складу такої ради навчальної програми входять керівник програми, викладачі, студенти, випускники та працедавці [6, с. 46].

Планування предметів спеціальності й занять 3 іноземної мови вимагає створення та збереження тісного контакту й взаєморозуміння між викладачами мови та викладачами предметів спеціальності (фрілософрії, психології, історії, літератури тощо). У багатьох країнах існує тенденція, коли майбутній учитель отримує підготовку 3 кількох предметів, що пізніше гарантує стабільне робоче навантаження в невеликих загальноосвітніх закладах. У таких випадках, як правило, між собою комбінують близькі за змістом предмети, наприклад, фрізику й математику, біологію та географрію, англійську й німецьку мови або українську та російську мови. Щодо кількості предметів, які відбираються для створення навчальних програм, як правило, намагаються об'єднати близькі природничі й гуманітарні науки (математику, мову, історію); різні природничі науки; теоретичні (фрундаментальні) та прикладні науки; природничі науки й гуманітарні; природничі й суспільні науки; іноземні мови та культурне середовище [5, с. 54]. Тому необхідно розуміти складність усього інтегрованого процесу, до якого залучаються завідувачі кафедр різних фракультетів, учителі загальноосвітніх навчальних закладів, де згодом студенти вливаються (інтегруються) в нові шкільні колективи й отримують оцінки за проходження педагогічної практики. Для набуття педагогічного досвіду та вдосконалення рівня іншомовної мовленнєвої компетенції студенти проходять педагогічну практику в загальноосвітніх навчальних закладах, де проводять уроки іноземної мови, розробляють позакласні навчальні заходи, а також виконують інші трансорормаційні завдання психологічного характеру, наприклад, організацію колективу та групового навчання, створення міцного іншомовного 
навчального середовища в групі учнів, що допомагає перевірити загальну мовленнєву компетенцію, асоціативну пам'ять, індуктивні мовленнєві здібності. Доцільно зауважити, що педагогічна практика майбутніх учителів стає своєрідною візитною карткою університету, очевидним показником рівня університетської підготовки, тому її результати можуть позитивно або негативно вплинути на партнерські стосунки між школами міста (області) та національним університетом, а це опосередковано пов'язано з проблемами регіональної політики.

Держава мусить розробити якісно нову стратегію підготовки й перепідготовки вчителів, зокрема викладачів іноземної мови [3, с. 7]. Безперервна освіта має продовжуватися протягом усього життя, однак запитаємо себе: чи багато українських учителів іноземної мови пройшли стажування за кордоном і підвищили свій рівень володіння тою мовою, якої мають навчати? У багатьох університетах розвинутих країн світу студенти, які навчаються за програмами підготовки вчителів, проходять стажування за кордоном протягом одного семестру, щоб краще зрозуміти психологію багатомовності й різних культур. Провідне місце в структурі професійного мислення фрахівця посідає психологічне мислення, тому майбутній учитель іноземної мови має передбачати основні труднощі лінгвістичного й психологічного характеру, що можуть виникати на уроках у різних комунікативних ситуаціях.

Висновки. Отже, загальна педагогічна стратегія розвитку вищої освіти передбачає створення в рамках вищої школи реального іншомовного навчального середовища, яке, ґрунтуючись на принципах професійної діяльності конкретних спеціальностей і принципах інтегрованого навчання предмета й мови, буде максимально сприяти ефективному оволодінню студентами й майбутньою професією, і професійно-орієнтованою іноземною мовою.

Процес цілісного, системного, різнобічного навчання профресії передбачає перехід від навчання спеціальності й іноземної мови як окремих предметів до реальної міжпредметної інтеграції. Упровадження методики інтегрованого навчання предмета й мови у вищій школі вимагає організації активної співпраці викладачів предметів спеціальності та викладачів іноземної мови. Розроблення й координація навчальних і предметних програм, узгодження їх змісту різними кафредрами, наступна корекція всього процесу інтегрованого навчання з урахуванням результатів педагогічної практики студентів можуть суттєво підвищити ефрективність професійної підготовки майбутніх фрахівців у вищій школі. Не менш важливим для вищої школи має стати врахування змістових компонентів педагогічного та психологічного характеру, що є необхідними для інтеграції навчання предмета й мови в рамках методичної, педагогічної та психологічної наук.

\section{БІБЛІОГРАФІЧНИЙ СПИСОК}

1. Александров В.М., Александрова О.Ф. Впровадження професійно-орієнтованого інтегрованого навчання предмета і мови у вищій школі. Педагогічні науки: зб. наук. пр. / Index Copernicus International, Херсонський державний університет. Херсон, 2018. C. 108-112.

2. Морська Н.О. Інтегрований підхід до викладання іноземної мови. Проблеми лінгвістики науково-технічного і художнього тексту та питання лінгвометодики. Вісник Національного університету «Львівська політехніка». Львів: Видавництво Національного університету «Львівська політехніка», 2001. № 419. С. 18-20.

3. Ничкало Н.Г. Перспективи розвитку професійної освіти і проблеми підготовки педагогів нової генерації. Педагог профресійної школи: зб. наук. пр. / редкол.: Н.Г. Ничкало (голова), І.А. Зязюн, О.І. Щербак та ін.; упоряд. Н.Г. Ничкало, О.І. Щербак. Київ: Наук. світ, 2003. Вип. V. 281 с. С. 4-12.

4. Сова М.О. Інтеграція художньо-культурологічних знань у системі профресійної підготовки вчителя гуманітарних дисциплін: автореср. дис. ... докт. пед. наук: 13.00.04 «Теорія і методика профресійної освіти». Київ, 2005. 43с.

5. Шевчук К. Інтегрований підхід до навчання: ретроспективний аналіз. Наукові записки Вінницького державного педагогічного університету ім. М. Коцюбинського. Серія «Педагогіка і психологія». 2007. № 20. C. 50-55.

6. Раннут М., Райк К. Подготовка студентов педагогических вузов к интегрированному преподаванию предмета и языка. Пособие по разработке учебных программ и подготовке будущих учителей к работе в многоязычной школе. Нарва, 2016. 77 с. 